\title{
Review
}

\section{Management of herbicide-tolerant oilseed rape in Europe: a case study on minimizing vertical gene flow}

\author{
Yann DEVOS ${ }^{1 \star}$, Dirk REHEUL ${ }^{2}$, Adinda DE SCHRIJVER ${ }^{1}$, François CORS $^{3}$ and William MOENS ${ }^{1}$ \\ ${ }^{1}$ Service of Biosafety and Biotechnology, Scientific Institute of Public Health, Juliette Wytsmanstraat 14, 1050 Brussels, Belgium \\ ${ }^{2}$ Department of Plant Production, Faculty of Bioscience Engineering, University of Ghent, Coupure Links 653, 9000 Ghent, Belgium \\ ${ }^{3}$ Department of Pesticide Research, Walloon Agricultural Research Centre, Rue du Bordia 11, 5030 Gembloux, Belgium
}

\begin{abstract}
The potential commercialization of genetically modified herbicide-tolerant (GMHT) oilseed rape in Europe raises various concerns about their potential environmental and agronomic impacts, especially those associated with the escape of transgenes. Pollen of oilseed rape can be dispersed in space, resulting in the fertilization of sympatric compatible wild relatives (e.g. Brassica rapa) and oilseed rape cultivars grown nearby (GM and/or non-GM Brassica napus). The spatial and temporal dispersal of seeds of oilseed rape may lead to feral oilseed rape populations outside the cropped areas and oilseed rape volunteers in subsequent crops in the rotation. The incorporation of a HT trait(s) may increase the fitness of the recipient plants, making them more abundant and persistent, and may result in weeds that are difficult to control by the herbicide(s) to which they are tolerant. Vertical gene flow from transgenic oilseed rape to non-GM counterparts may also have an impact on farming and supply chain management, depending on labelling thresholds for the adventitious presence of GM material in non-GM products. Given the extent of pollen and seed dispersal in oilseed rape, it is obvious that the safe and sound integration of GMHT oilseed rape in Europe may require significant on-farm and off-farm management efforts. Crucial practical measures that can reduce vertical gene flow include (1) isolating seed production of Brassica napus, (2) the use of certified seed, (3) isolating fields of GM oilseed rape, (4) harvesting at the correct crop development stage with properly adjusted combine settings, (5) ensuring maximum germination of shed seeds after harvest, (6) controlling volunteers in subsequent crops, and (7) keeping on-farm records. The implementation of the recommended practices may, however, be difficult, entailing various challenges.
\end{abstract}

Keywords: Brassica napus / vertical gene flow / volunteers / feral oilseed rape / wild relatives / herbicide tolerance / biosafety / risk management / co-existence

\section{INTRODUCTION}

In Europe, oilseed rape (Brassica napus) is an important non-cereal crop that is grown in both spring and winter forms. The oil extracted from the seeds of oilseed rape is used for various food and industrial applications, and the meal remaining after seed crushing is used as a proteinrich component in animal feed. Oilseed rape is mostly grown as a breaking crop in a 3 to 4 -year rotation with the cereals wheat (Triticum aestivum) and barley (Hordeum vulgare). Breaking a sequence of cereal crops with oilseed rape helps to control weeds and plant diseases occurring in cereals.

To date, different genetically modified (GM) oilseed rape events with tolerance to the non-selective herbicides containing the active ingredients glufosinate or glyphosate are in the European pipeline for commercialization (Tab. 1). In 1996, the transgenic events MS1, RF1 and MS1 $\times$ RF1 received authorization for cultivation for seed production, but have not been grown commercially

\footnotetext{
* Corresponding author: Yann.Devos@UGent.be

Current address: Department of Plant Production, Faculty of Bioscience Engineering, University of Ghent, Coupure Links 653, 9000 Ghent, Belgium.
} 
Y. Devos et al.

Table 1. Overview and state of play on GMO authorisations of transgenic HT oilseed rape events under the European directives (90/220/EEC, 2001/18/EC) on the deliberate release into the environment of GMOs for commercial purposes (August 2004; Belgian Biosafety Server: http://www.biosafety.be).

\begin{tabular}{|c|c|c|c|c|}
\hline Event(s) & "Notification number & Engineered trait(s) & Commercial application(s) & State of play \\
\hline $\mathrm{MS} 1 \times \mathrm{RF} 1$ & C/UK/94/M1/1 & $\begin{array}{l}\text { glufosinate tolerance, barnase/ } \\
\text { barstar hybrid system }\end{array}$ & growing & authorized \\
\hline $\mathrm{MS} 1 \times \mathrm{RF} 1$ & $\mathrm{C} / \mathrm{F} / 95 / 05-01 \mathrm{~A}$ & $\begin{array}{l}\text { glufosinate tolerance, barnase/ } \\
\text { barstar hybrid system }\end{array}$ & growing, import, processing, feed & $\begin{array}{l}\text { authorization } \\
\text { not issued }\end{array}$ \\
\hline $\mathrm{MS} 1 \times \mathrm{RF} 2$ & $\mathrm{C} / \mathrm{F} / 95 / 05-01 \mathrm{~B}$ & $\begin{array}{l}\text { glufosinate tolerance, barnase/ } \\
\text { barstar hybrid system }\end{array}$ & growing, import, processing, feed & $\begin{array}{l}\text { authorization } \\
\text { not issued }\end{array}$ \\
\hline Topas $19 / 2$ & C/UK/95/M5/1 & glufosinate tolerance & import, processing, feed & authorized \\
\hline MS8 $\times$ RF3 & $\mathrm{C} / \mathrm{BE} / 96 / 01$ & $\begin{array}{l}\text { glufosinate tolerance, barnase/ } \\
\text { barstar hybrid system }\end{array}$ & growing, import, processing, feed & pending \\
\hline $\begin{array}{l}\text { Falcon GS40/ } \\
90 \mathrm{pHoe} 6 / \mathrm{ac}\end{array}$ & $\mathrm{C} / \mathrm{DE} / 96 / 05$ & glufosinate tolerance & growing, import, processing, feed & pending \\
\hline Liberator pHoe6/Ac & $\mathrm{C} / \mathrm{DE} / 98 / 06$ & glufosinate tolerance & growing, import, processing, feed & pending \\
\hline GT73 & C/NL/98/11 & glyphosate tolerance & import, processing, feed & pending \\
\hline $\mathrm{T} 45$ & $\begin{array}{l}\mathrm{C} / \mathrm{GB} / 99 / \mathrm{M} 5 / 2 \\
\text { replaced by } \\
\mathrm{C} / \mathrm{GB} / 04 / \mathrm{M} 5 / 4\end{array}$ & glufosinate tolerance & import, processing, feed & pending \\
\hline
\end{tabular}

in Europe yet. The import of seeds of event Topas 19/2 for processing purposes is also allowed.

The environmental and agronomic concerns associated with the escape of herbicide tolerance (HT) trait(s) to wild relatives and to other oilseed rape cultivars (GM and non-GM) have received much attention (Dale, 1992, 1994; Eastham and Sweet, 2002; Ellstrand, 1992, 2003; Ellstrand and Hoffman, 1990; Ellstrand et al., 1999; Hoffman, 1990; Kareiva et al., 1994; Raybould and Gray, 1993; Schiemann, 2003; Snow, 2002; Snow and Palma, 1997; Tiedje et al., 1989). The HT trait(s) may confer a benefit to certain weedy relatives resulting in the evolution of weeds that may be difficult to control and/or become more abundant. Uncontrolled HT plants can act as an undesired pollen source and add seeds into the seed bank, thereby increasing the spread of the transgene(s) in space and time. Given the established thresholds for the adventitious presence of GM material in non-GM produce in Europe (0.1-0.9\% for organic products, $0.3 \%$ for oilseed rape seed and $0.9 \%$ for conventional products), growing transgenic oilseed rape is predicted to have an impact on farming and supply chain management.

If authorizations for commercial release are granted, the safe and sound integration of GMHT oilseed rape in Europe may require additional on-farm and off-farm management efforts. The present review analyses vertical gene flow in oilseed rape and its potential environmental and agronomic consequences, discusses which practical on-farm and off-farm measures can help to minimize ver- tical gene flow, and what challenges these management measures may entail. Food safety consequences of vertical gene flow are not addressed in the present review.

\section{VERTICAL GENE FLOW IN OILSEED RAPE}

Vertical gene flow refers to the sexual transfer of genes between two genetically different living plants or populations. In oilseed rape, genes can be transferred between cultivars (crop-to-crop), and from cultivars to certain wild relatives (crop-to-wild), volunteers and feral plants. Volunteers are plants emerging within agricultural fields as a result of previous cropping, while feral plants are domesticated plants reverting to the wild type outside the cropped area. Important steps in vertical gene flow are the spread of the (trans)gene(s) to other plants or populations, the formation of $\mathrm{F}_{1}$ hybrids, and the stabilisation of the (trans)gene(s) by introgression (Chèvre et al., 2004; Ellstrand, 2003; Jenczewski et al., 2003; van Tienderen, 2004). In oilseed rape, the (trans)gene(s) can be spread in space through pollen and seeds, and in time through seeds in the seed bank (Eastham and Sweet, 2002; Rieger et al., 1999; Salisbury, 2002; Warwick et al., 2004).

\section{Pollen dispersal in space}

The onset for a successful fertilization of an ovule is obtained when viable oilseed rape pollen is deposited on 
Review: Management of herbicide-tolerant oilseed rape in Europe

a compatible stigma. In vitro germination experiments revealed that oilseed rape pollen remains viable for 24 hours to 1 week (Eastham and Sweet, 2002). Fertilization of oilseed rape usually results from self-pollination, although interplant out-crossing rates of $12-47 \%$ with an average of $30 \%$ have been reported (Becker et al., 1992; Beckie et al., 2003). The pollen, which is heavy and sticky, can be transferred from plant to plant through physical contact between their flowers, by wind, or insects. Insects like honeybees (Apis mellifera) and pollen beetles (Meligethes aeneus) play an important role in pollen dispersal over longer distances. Bumblebees (Bombus terrestris) on the other hand, having higher site fidelity than honeybees, transfer the collected pollen within shorter distances of the first collection point (Cresswell et al., 1995, 2002; Osborne et al., 1999; Ramsay et al., 1999, 2003; Scheffler et al., 1993, 1995; Simpson et al., 1999; Timmons et al., 1995, 1996). The flowering period of individual oilseed rape plants generally lasts 3 to 4 weeks.

In field studies differing in location, environmental conditions and experimental design, crossing between oilseed rape plants has been detected at up to $4000 \mathrm{~m}$ from the pollen source (Ramsay et al., 1999; Rieger et al., 2002; Thompson et al., 1999). Ramsay et al. (2003) even detected very low levels of fertilisations on male-sterile plants at 5 and $26 \mathrm{~km}$ of the nearest known pollen source. The vast majority of the cross-pollinations have been shown to occur over short distances. Pollen concentrations and consequently successful pollinations tend to decline rapidly with distance from the source following an exponential or a leptokurtic pattern with long tails. At distances further than $100 \mathrm{~m}$ from the source, the percentage of dispersion is maintained at a very low level and does not appear to decrease in any clear manner with distance (Beckie et al., 2001, 2003; Bilsborrow et al., 1998; Champolivier et al., 1999; Eastham and Sweet, 2002; Gray and Raybould, 1998; Hall et al., 2003; Ingram, 2000; Kareiva et al., 1994; Lavigne et al., 1998; Mesquida and Renard, 1982; Paul et al., 1995; Ramsay et al., 1999, 2003; Rieger et al., 2002; Salisbury, 2002; Scheffler et al., 1995; Simpson et al., 1999; Squire et al., 1999, 2003; Sweet, 2003; Thompson et al., 1999; Timmons et al., 1995, 1996).

\section{Seed dispersal in space}

Seeds of oilseed rape can be dispersed over short distances to non-agricultural areas or neighboring fields by wind, birds or machinery. It has been estimated that a combine can hold several kilograms of oilseed rape seeds after use (Sweet et al., 1997). Assuming a 1000 kernel weight of 4-5 g, accidental spillage of only $2 \mathrm{~kg}$ represents $\sim 400000$ to 500000 seeds. Dispersal over long distances results from seeds that are spilled during transport from fields on the way to handling, storing and/ or crushing facilities, or during import (Crawley and Brown, 1995; Norris and Sweet, 2002; Pessel et al., 2001; Salisbury, 2002; Simard et al., 2002; Sweet et al., 1997; Wilkinson et al., 1995).

Consequently, in many regions where oilseed rape is grown, feral oilseed rape populations are reported in nonnatural disturbed ecosystems, including field margins, roadsides, railway lines and wastelands (Crawley and Brown, 1995; Norris and Sweet, 2002; Pessel et al., 2001; Salisbury, 2002; Simard et al., 2002; Wilkinson et al., 1995). Owing to its opportunistic nature, early germination potential and capacity to capture resources rapidly (Blackshaw et al., 2003, 2004), oilseed rape can take advantage of disturbed land. Successful recruitment of oilseed rape from seed mainly depends on its ability to compete for space with primary colonizers, particularly perennial grasses. In most non-agricultural areas oilseed rape lacks the ability to survive due to the absence of competition-free gaps (Crawley et al., 1993; Warwick et al., 1999). Populations that have established outside the agricultural fields often go extinct after 2 to 4 years (Crawley and Brown, 1995; Crawley et al., 2001; Norris and Sweet, 2002), but other studies suggest that feral oilseed rape populations can persist far longer (810 years) (Lutman et al., 2004; Pessel et al., 2001; Squire et al., 2003; Wilkinson et al., 1995). Unless the habitats are disturbed on a regular basis (e.g. by mowing, herbicide application, soil disturbance) or replenished with seed from seed spillage from passing traffic, feral oilseed rape populations will eventually be displaced. Local extinctions may be followed by recruitment when the soil is disturbed, giving the impression of a permanent population.

\section{Seed dispersal in time}

Loss of seeds through the shattering of the seed-bearing pods before and during harvest is common in oilseed rape (Hobson and Bruce, 2002; Gulden et al., 2003a; Morgan et al., 1998; Price et al., 1996; Thomas et al., 1991). When the seeds reach maturity, the pods become fragile and easily split open, resulting in losses that can reach up to $10 \%$ of the seed yield. Under ideal harvest conditions yield losses range from 2 to $5 \%$, attaining up to $50 \%$ yield 
loss under unfavorable conditions. Given a potential seed yield of 2000-4 $000 \mathrm{~kg} / \mathrm{ha}$ and a 1000 kernel weight of $4-5 \mathrm{~g}$, a yield loss of 2 to $5 \%$ means a loss of $1000-5000 \mathrm{seeds} / \mathrm{m}^{2}$, which is 10 to 35 times more than the sowing rates of $80-150$ seeds $/ \mathrm{m}^{2}$.

Oilseed rape seeds have very little primary dormancy at harvest time (Gulden, 2003). As a consequence most of the shed seeds germinate within two years and fail to enter the seed bank, if appropriate germination conditions occur (Beismann et al., 2003; Hails et al., 1997; Lutman et al., 2002, 2004; Norris and Sweet, 2002; Roller et al., 2003). However, owing to environmental factors, some of the buried seeds can develop secondary dormancy and remain dormant for several years (Gulden, 2003; Gulden et al., 2003b; Lutman et al., 2004). Secondary dormancy can be induced in the absence of light or in response to water stress, oxygen deprivation or low temperatures. These conditions occur when seeds are buried immediately after harvest under dry conditions (Pekrun et al., 1997a).

The persistence of the secondarily dormant seeds has been confirmed to be up to 5 years, but may reach 10 years or more under field conditions (Lutman et al., 2004; Schlink, 1998). The duration of the persistence varies with the cultivar and the conditions of burial, with higher persistence at depth than near the surface, in heavy soils than in lighter ones, and in undisturbed environments (Chadoeuf et al., 1998; Gruber et al., 2004; Gulden, 2003; López-Granados and Lutman, 1998; Lutman et al., 2002, 2004; Momoh et al., 2002; Pekrun et al., 1997b; Pekrun et al., 2003; Pessel et al., 2001; Roller et al., 2003; Simard et al., 2002; Squire et al., 2003). Under normal cropping conditions ca. $5 \%$ of the shed seeds appear to survive for 2-5 years depending on the post-harvest tillage (Lutman, 2003; Lutman et al., 2004) representing approximately $50-250 \mathrm{seeds} / \mathrm{m}^{2}$. Fungal attack and/or invertebrate predation play a role in the degeneration of the viable seeds in the seed bank (Chadoeuf et al., 1998; Lutman et al., 2004).

Secondarily dormant seeds can germinate and emerge from the seed bank in the following years, and cause weed problems, particularly in broad-leaved crops. Exposure to dormancy-breaking stimuli by bringing buried seeds to the surface as a result of soil handling will result in the emergence of oilseed rape seedlings. With a seed loss of $6000 \mathrm{seeds} / \mathrm{m}^{2}$ at harvest, inappropriate post-harvest tillage and an emergence of oilseed rape seedlings up to 2-4\%, Lutman et al. (2004) estimated that there could be $6-15$ volunteers $/ \mathrm{m}^{2}$ in the next oilseed rape crop grown in a 4-year rotation. These volunteer numbers correspond to about $10 \%$ of the sown seeds.

\section{Hybridization and introgression with wild relatives}

Oilseed rape is known to hybridize with other oilseed rape cultivars and certain wild relatives. Compared to the hybridization frequencies within cultivars (intra-specific), hybridization with wild relatives (inter-specific) will occur at a much lower level because most of the wild relatives are partially or fully isolated by breeding barriers. In addition, ecological barriers play an important role in limiting the process of inter-specific gene flow (Chèvre et al., 2004; Ellstrand, 2003; Jenczewski et al., 2003; Salisbury, 2002; van Tienderen, 2004). Therefore, the probability of inter-specific gene flow is very low, but nevertheless greater than zero (Ellstrand, 2003; Ellstrand et al., 1999; Raybould and Gray, 1993; van Tienderen, 2004).

Scheffler and Dale (1994) established a relative ranking of wild relatives based on the ease with which oilseed rape crosses with wild related species, and forms hybrids $\left(\mathrm{F}_{1}\right), \mathrm{F}_{2}$ and backcross $(\mathrm{BC})$ progeny. Here, data on hybridization and introgression of B. napus with the most closely related and common wild relatives in Europe ranked according to Scheffler and Dale (1994) are discussed (Chèvre et al., 2004; Eastham and Sweet, 2002).

Brassica rapa: Evidence of introgression of transgenes of oilseed rape into wild/weedy $B$. rapa populations was given in field experiments (Bing et al., 1996; Hansen et al., 2001; Jørgensen et al., 2004) and commercial agricultural settings (Norris et al., 2004; Warwick et al., 2003). Depending on the parental genotypes, experimental design, agricultural practices and site, the hybrid frequencies ranged from 0 to $69 \%$ (Jørgensen et al., 1999, 2004). In the wild habitat of $B$. rapa along riverbanks, hybridization frequencies were very low (Scott and Wilkinson, 1998; Wilkinson et al., 2000) whilst higher frequencies were found where $B$. rapa occurs as a weed in oilseed rape (Norris et al., 2004). The $\mathrm{F}_{1}, \mathrm{~F}_{2}$ and $\mathrm{BC}$ generations tended to be rather fertile and fit (Hauser et al., 1998a, 1998b, 2003). In addition, there was no fitness cost associated with the acquisition of the HT trait (Snow et al., 1999). Introgression is likely to take place when both species are present in the same area (sympatric) over several growing seasons (Jørgensen et al., 2003, 2004).

Brassica juncea: Spontaneous hybridization between oilseed rape and $B$. juncea has been reported. Depending on the proportions between the parental species up to $3 \%$ of B. juncea offspring were hybrids (Bing et al., 1995, 1996; Frello et al., 1995; Jørgensen et al., 1998). Although the hybrids had low pollen fertility (0-28\%), the transfer 
Review: Management of herbicide-tolerant oilseed rape in Europe

of oilseed rape markers to the first backcross generation with $B$. juncea was observed. In the $\mathrm{BC}_{1}$ plants, pollen fertility improved (24-90\%) compared to that of the hybrids (Frello et al., 1995). The results suggest that introgression is possible, but until now no information is available to confirm if introgression will occur under agricultural settings and how sustainable it will be.

Brassica oleracea: After hand pollinating B. oleracea with oilseed rape pollen, inter-specific hybrids have been obtained. In the field, however, spontaneous hybridization is unlikely. Wild populations of B. oleracea naturally grow in coastal cliffs and are therefore rarely sympatric with oilseed rape cultivars (Chèvre et al., 1997, 2004).

Brassica nigra: Given the very low levels of hybridization between oilseed rape and $B$. nigra under controlled conditions, gene escape under open pollination conditions in the field is unlikely (Bing et al., 1996).

Raphanus raphanistrum: Under agronomic conditions hybrids with low fertility were found in very small numbers on $R$. raphanistrum (frequency of $10^{-5}$ to $10^{-7}$ ) (Chèvre et al., 2000; Rieger at al., 2001; Warwick et al., 2003). During successive generations of backcrossing, fertility recovered but the percentage of HT plants decreased indicating that the transgene had not been introgressed into the $R$. raphanistrum genome. Cytoplasmic incompatibility markedly reduced the vigor and viability of $\mathrm{BC}_{5}$ and $\mathrm{BC}_{6}$ (Chèvre et al., 1998; Guéritaine et al., 2002).

Hirschfeldia incana: Hybrids between oilseed rape and $H$. incana spontaneously occurred in field experiments (Lefol et al., 1996b). However, after five generations of backcrossing to $H$. incana, no introgression was detected into $H$. incana. Due to the low fertility of the hybrids and genome incompatibility, backcross plants are very rare, and the likelihood of transgene loss in subsequent generations is high (Darmency and Fleury, 2000).

Sinapis arvensis: No hybrids have been detected under field conditions, indicating that introgression is unlikely. Different studies showed that there is a limited potential to produce hybrids even under the most favorable breeding conditions (Bing et al., 1996; Chèvre et al., 1996; Lefol et al., 1996a; Moyes et al., 2002; Warwick et al., 2003).

In conclusion, several inter-specific hybrids have been described between oilseed rape and its wild relatives, but under field conditions, gene introgression has only been confirmed for B. napus-B. rapa hybrids (Chèvre et al., 2004). It is important to note that in agricultural fields, the extent of vertical gene flow from oilseed rape towards certain weedy relatives will depend on the agricultural and weed control practices. The development of HT weedy relatives is expected to be slow in conventionally managed fields (Hauser et al., 2003; Jørgensen et al., 2004; Norris et al., 2004; Pertl et al., 2002).

\section{ENVIRONMENTAL AND AGRONOMIC IMPACTS RESULTING FROM VERTICAL GENE FLOW}

Various concerns have been raised about the uncontrolled escape of transgenes into weeds, feral oilseed rape and certain wild relatives, and into neighboring fields with oilseed rape. The major concern is that the incorporation of the HT trait(s) in recipient plants may enhance the fitness of these plants, making them more abundant and persistent. Theoretically, and depending on which transgenic traits are involved, altered fitness may enable the plants to expand and invade new habitats, with unwanted effects on other species and ecosystem integrity (Crawley et al., 1993; Dale, 1992, 1994; Ellstrand, 1992, 2003; Ellstrand et al., 1999; Hoffman, 1990; Kareiva et al., 1994; Raybould and Gray, 1993; Tiedje et al., 1989; Wilkinson et al., 1995). Oilseed rape is, however, generally regarded as an opportunistic species, and not as an environmentally hazardous colonizing species (Beckie et al., 2001; Warwick et al., 1999). Moreover, several field studies report that the presence of a HT trait in oilseed rape does not confer a competitive advantage, unless the herbicide is applied. In the absence of the relevant herbicide, HT plants are not more invasive or persistent than untransformed control plants (Beckie et al., 2001; Crawley et al., 1993, 2001; Downey, 1999; Fredshavn et al., 1995; Norris and Sweet, 2002; Norris et al., 1999; Simpson et al., 1999; Warwick et al., 1999, 2004; Wilkinson et al., 1995). The numbers of HT volunteers in the years following the cultivation of transgenic HT oilseed rape appear to be comparable to, or less than the amount of volunteers in conventional oilseed rape (Beismann et al., 2003; Crawley et al., 1993; Gulden, 2003; Hails et al., 1997; Norris and Sweet, 2002; Norris et al., 1999; Roller et al., 2003; Simard et al., 2002; Sweet et al., 1997; Wilkinson et al., 1995).

If HT plants (volunteers, ferals and wild relatives) remain uncontrolled and reproduce, they may serve as a gene reservoir that could hold and return the HT trait(s) to oilseed rape cultivars in a different place and time, and act as a genetic bridge delivering the HT trait(s) to sympatric sexually compatible plants (Beckie et al., 2003; Ellstrand, 2003; Warwick et al., 1999, 2003, 2004; Wilkinson et al., 1995). The transgene(s) may thereby increase in frequency in space and time. However, the 
Y. Devos et al.

Table 2. Overview of some herbicide active ingredients that remain effective to control transgenic volunteers that are tolerant to glyphosate and/or glufosinate in subsequent crops in the rotation in Europe (http://www.fytoweb.fgov.be; http://ephy.agriculture.gouv.fr/wiphy; http://www.bba.de; http://www.ctb-wageningen.nl; http://www.pesticides.gov.uk) *.

\begin{tabular}{ll}
\hline \hline Subsequent crop & Volunteer control practice \\
\hline Cereal crops & $\begin{array}{l}\text { bentazon, bromoxynil, diflufenican, hormone-type (2,4-D, MCPA), linuron, mecoprop-P, } \\
\text { methabenzthiazuron, metsulfuron-methyl, paraquat, prosulfocarb, triasulfuron, trifluralin }\end{array}$ \\
Sugar beet (Beta vulgaris) & metamitron, trifluralin, triflusulfuron-methyl \\
Pea (Pisum sativum), bean (Phaseolus vulgaris) & aclonifen, bentazon, flurochloridon, linuron, methabenzthiazuron, pendimethalin \\
Potato (Solanum tuberosum) & aclonifen, flurochloridon, linuron, metribuzin, prosulfocarb, rimsulfuron \\
Sunflower (Helianthus annuus) & aclonifen, pendimethalin, flurochloridon \\
\hline
\end{tabular}

* Subject to national registration and availability of active ingredient.

contribution of the above mentioned HT plants in vertical gene flow is expected to be of much smaller importance than that of the HT crop plants themselves. Nevertheless, in the context of co-existence between GM and non-GM crops their contribution may be relevant (Colbach et al., 2001a, 2001b; Schiemann, 2003).

In agro-ecosystems, herbicide treatments are commonly applied to control weeds, including oilseed rape volunteers and certain wild relatives. A widespread concern is that HT oilseed rape volunteers and HT wild/ weedy relatives may complicate the application of herbicides, because these HT plants can no longer be controlled by the herbicide(s) to which they are tolerant. Herbicide application may then be shifted back to the present situation where several compounds have to be applied to control weed infestation. Initially, the problem is expected to be less severe for HT wild relatives because of their significantly fewer numbers compared to volunteers. A concern over the long-term may be the occurrence of multiple HT oilseed rape volunteers and HT wild relatives when cultivars that are tolerant to different herbicides are grown in proximity. Multiple HT oilseed rape volunteers have already been reported under commercial agricultural settings in Canada (Beckie et al., 2003; Downey, 1999; Hall et al., 2000, 2003; Orson, 2002). Pollen flow between different HT oilseed rape cultivars is the most likely explanation for the observed multiple herbicide tolerance (Beckie et al., 2003; Hall et al., 2000). Multiple HT oilseed rape volunteers were also observed in specifically designed multi-year field experiments with HT oilseed rape in France (Champolivier et al., 1999; Messéan, 1997), Germany (Dietz-Pfeilstetter and Zwerger, 2003) and the UK (Simpson and Sweet, 2001; Simpson et al., 1999). To date, single and multiple HT volunteers, including those that have non-transgenic (conventionally bred) herbicide tolerance, have caused few problems for Canadian farmers growing oilseed rape for seed to be processed into oil (Beckie et al., 2004; Ellstrand, 2003; Warwick et al., 2004). Whilst HT weeds can no longer be controlled by the herbicide(s) for which resistance is obtained, a set of currently used selective broad-leaf herbicides or herbicide mixtures remain effective against these HT volunteers and HT wild relatives (Tab. 2) (Beckie et al., 2001, 2004; Hall et al., 2000, 2003; Orson, 2002; Orson and Oldfield, 1999; Salisbury, 2002; Senior and Dale, 2002; Senior et al., 2002). However, farmers or seed producers converting to agricultural practices with low herbicide usage may experience problems with HT weeds. Also, uncontrolled HT weeds may render it difficult to comply with the established labelling thresholds for the adventitious presence of GM material in non-GM produce or to achieve the seed purity standards (Jørgensen et al., 2004; Warwick et al., 2004).

Along roadsides and railway lines, and in field margins, HT feral oilseed rape and HT wild relatives can also be challenged by weed control. If weed control is carried out, it is generally done by mowing or by the application of herbicides containing glyphosate. Due to tolerance to the active ingredient and the reduced plant competition after herbicide use, applying glyphosate may temporarily increase the fitness of glyphosate tolerant feral oilseed rape and wild relatives. However, the impact thereof has not been studied yet. In addition, the potential transient impact of herbicide drift on the establishment and persistence of HT feral oilseed rape and HT wild relatives in field margins also remains an open question.

Given the established labelling thresholds for the adventitious presence of GM material in non-GM produce in Europe, the cultivation of GM crops is predicted to have an impact on farming and supply chain management. Cross-pollinations between neighboring fields with GM and non-GM oilseed rape cultivars, the emergence of secondarily dormant GM oilseed rape seeds from the seed bank in the next non-GM oilseed rape grown in a 
Review: Management of herbicide-tolerant oilseed rape in Europe

4-year rotation, and admixing of GM and non-GM seeds can introduce impurities. In Canada, impurities above the permitted threshold $(0.25 \%)$ have already been found in commercial certified oilseed rape seed lots (Friesen et al., 2003). Co-existence between GM and non-GM production will thus raise questions about the management of the adventitious mixing of GM and non-GM products and the potential economic implications thereof, the opportunity for farmers to choose a crop they want to grow, and the maintenance of different production systems to provide a high degree of consumer choice (Schiemann, 2003).

\section{MANAGEMENT FOR REDUCING VERTICAL GENE FLOW}

From the information given in the previous paragraphs, it is obvious that vertical gene flow is a relevant issue in oilseed rape and that management efforts might be needed for the integration of transgenic HT oilseed rape in Europe. Based on the achieved experience in certified seed production, identity preservation and quality assurance systems, a set of measures with varying levels of efficacy can be recommended for minimizing vertical gene flow.

\section{Practical measures to limit pollen dispersal in space}

Although the need to prevent crop pollen from escaping to other plants is a relatively new issue in agronomy, the reverse problem is something plant breeders have been concerned with for half a century during the production of certified seed. Seed producers commonly use isolation distances and/or border rows (pollen trap plants) to limit the amount of immigrating pollen and assure that the produced seed fulfil the required purity standards. It is important that any seed production of Brassica crops remains tightly restricted to suitably isolated areas. Isolation distances and/or border rows can also be put in place to limit pollen flow between GM and non-GM oilseed rape cultivars or different types of HT oilseed rape grown on adjacent farms.

When defining appropriate isolation distances and/or border rows, various factors need to be taken into account because out-crossing rates generally show a considerable amount of variation between years, sites, replicates within and between sites, experimental designs and agricultural practices (Eastham and Sweet, 2002; Ellstrand, 2003; Ingram, 2000; Klinger and Ellstrand, 1999; Salisbury, 2002; Sweet, 2003). Models can offer a potential solution to address this variation. Based upon experiments in the field, these models are being developed to predict pollenmediated gene flow at landscape level, under different spatial distributions of oilseed rape cultivars and different cropping systems (Baker and Preston, 2003; Colbach et al., 2001b; Simpson and Sweet, 2004; Squire et al., 1999; Walklate et al., 2004).

Similar isolation distances and/or border rows can be envisaged to limit the flow of transgenes into populations of wild relatives. However, considering the irregular distribution of the relevant wild relatives, appropriate isolation distances may be very difficult to manage (Snow, 2002). Ellstrand (2003) reported that isolation distances are a crude, costly, and probably an ineffective way to manage gene flow between a cultivar and its compatible wild relatives. Genetic based methods limiting or preventing transgene escape towards certain wild relatives could provide a solution. For example, engineering the chloroplast genome of oilseed rape might be an option because chloroplasts are mostly inherited maternally (Daniell, 2002; Ellstrand, 2003; Gray and Raybould, 1998). Scott and Wilkinson (1999) showed that the maternal inheritance of chloroplasts in hybrids between cultivated oilseed rape and wild $B$. rapa occurred at levels of about $2 \%$.

\section{Practical measures to limit seed dispersal in space}

During sowing, harvest, handling and transport, seed losses and admixtures are known to occur, but few data are published on the incurred amounts of seed spillage and admixing. Best practices to limit seed admixing can start with recording of the seed receipt, and verifying that the seed packages are undamaged and labelled properly. The separate storage in the original packaging with an obligatory label can avoid admixing. The surplus of GM seeds left after sowing can be kept apart in labelled resealed bags because the farmer might use it later or resell it to the seed supplier.

At sowing and harvesting time, cleaning thoroughly the seed drilling and harvesting equipment before and/or after use and before entering or leaving the field can reduce seed movement off-fields and admixtures. Although it is important that equipment is properly cleaned, it will not totally eliminate seed spillage and admixing of transgenic seeds. The seeds of oilseed rape are small, rendering the cleaning operation difficult and time consuming. Harvesting contractors need to work quickly in regions with temperate and rapidly changing weather conditions. Hence, they might not like to lose a 
lot of time by cleaning their machinery. The installation of an air compressor on harvesters may facilitate the cleaning operation. Cleaning the machinery that is involved in the storage, aeration, drying, coating and packaging of the harvested transgenic seeds is also recommended, but may again be difficult to fulfil in all circumstances. In the end, the use of physically separated supply chains may be the only option to avoid seed admixing. However, in regions where the oilseed rape production is small, this alternative is not likely to be feasible.

Sealing vehicles that transport the seeds or covering seed loads during transport reduces seed losses. However, a problem may reside in the warming up of the viable seeds under hermetically closed conditions. Where seed spillage of GM seeds has occurred, sweeping, shovelling or vacuum cleaning the seeds into sealed containers can limit the establishment of transgenic feral oilseed rape populations. Monitoring the occurrence of feral oilseed rape plants can be a first step for their control. Feral oilseed rape is efficiently controlled by mowing or herbicide treatment before seed setting. To avoid the use of herbicides in natural circumstances, mowing is preferred. Moreover, spraying the wrong herbicide may give a temporally selective advantage to the HT feral oilseed rape plants. Repeated mowing treatments during the season may be required because feral oilseed rape populations generally consist of individuals that flower when the plant is very small or at various times or late in the season. A model that is in development may provide better insights on the optimal management strategy of feral oilseed rape populations (Deville et al., 2003).

\section{Practical measures to limit seed dispersal in time}

Different practical measures can help to reduce the losses of oilseed rape seeds during harvest, the amount of seeds entering the seed bank and seed return by weeds. During the harvest of oilseed rape, seed loss is influenced by the stage of maturity of the pods, the weather conditions, the settings of the harvesting equipment, and the speed of the harvesting operation. Harvesting at the optimum stage of pod development gives lower losses than harvesting at later dates. Delaying harvest may double the seed losses (Thomas et al., 1991). Compared to spring oilseed rape, the determination of the optimal harvest moment of winter oilseed rape is more difficult, owing to the longer, less uniform period of seed ripening (Morgan et al., 1998; Price et al., 1996; Thomas et al., 1991). The drier the pods are the more seed losses occur, which is the case during spells of hot and windy weather. Therefore, avoiding harvest at high temperatures and low air humidity, and during windy conditions can reduce seed losses (Thomas et al., 1991). The two harvest methods commonly used in oilseed rape are direct cutting of the standing plants in a single operation, with or without chemical desiccation, or a two-stage harvest involving swathing the crop at an early stage of ripening followed by a 7 to 14 day period of ripening in the swath. With the development of oilseed rape cultivars that are shorter in height and more tolerant to lodging, the harvest method switched to direct cutting in Europe. Swathing is now limited to adverse weather conditions because the ripening of the crop is protected within a well-formed swath. Given that seed losses tend to be higher during direct cutting than during swathing, several devices have been developed to reduce seed losses (Hobson and Bruce, 2002; Price et al., 1996; Shirtliffe and Entz, 2004; Thomas et al., 1991). Some of these are the use of a conveyor-assisted header, preventing cut plants from being crushed by the auger before they pass the cutterbar. A vertical cutterbar on the header limits lateral losses of seeds resulting from the breaking of the interlaced plant stems. A chaff collection system reduces seed losses at the rear of the harvester. Improper speed of the harvest operation contributes to higher seed losses (Gulden et al., 2003a). It should be noticed that seed losses resulting from delayed harvesting or harvesting during bad weather conditions tend to be greater than seed losses incurred by different harvest methods (Lutman, 2003; Pekrun et al., 2003; Thomas et al., 1991). Research is ongoing to develop pod shatter resistant cultivars, but progress has been difficult as the intrinsic variability within the germplasm of commercial cultivars is small for this characteristic (Morgan et al., 1998). Recently, several genes playing an essential role in pod dehiscence have been identified in Arabidopsis thaliana what may enable the design of approaches to engineer pod shatter resistance in oilseed rape (Rajani and Sundaresan, 2001).

After harvest, the time and type of tillage affect the entry of shed seeds into the seed bank and their persistence (Gruber et al., 2004; Lutman, 2003; Pekrun and Lutman, 1998; Pekrun et al., 1998, 2003; Roller et al., 2003; Simard et al., 2002). In oilseed rape, deep inversion tillage clearly appears to maximize the buildup of the soil seed bank, because the buried seeds develop secondary dormancy. On the opposite, leaving the shed seeds on the soil surface maximizes their germination, avoiding the replenishment of the seed bank. Farming in zero-tillage systems whereby the soil is left undisturbed from harvest to planting might therefore be the best option. However, for many European 
Review: Management of herbicide-tolerant oilseed rape in Europe

farmers zero-tillage is not common practice (Pekrun and Lutman, 1998; Pekrun et al., 1998). In addition, zerotillage enables the growth of volunteers from overwintering seedlings (Gruber et al., 2004). An alternative is to delay post-harvest cultivation for 3-4 weeks, which proves to be very effective to maximize germination of shed seeds in European regions where relatively high temperatures from August until October and intermittent rain are common (Gruber et al., 2004; Pekrun and Lutman, 1998; Pekrun et al., 1998; Roller et al., 2003). Delaying the first post-harvest tillage operation does not cause any agronomic difficulty, as winter wheat is often grown after oilseed rape leaving a sufficient gap between the harvest of oilseed rape and the installation of the wheat (Pekrun et al., 1998). The type of primary tillage also tends to be relevant. Gruber et al. (2004) recently reported that ploughing instead of using a cultivator before the sowing of the following crop account for an additional reduction of the seeds expected to germinate in the following crop. Another factor inducing the germination of surface seeds is rainfall. Approximately $10 \mathrm{~mm}$ rainfall tends to be appropriate and even $4 \mathrm{~mm}$ seems to be sufficient in cool conditions. Cultivation can therefore be delayed until rain has stimulated many surface seeds to germinate (Lutman et al., 2004). Seed persistence is not only affected by environment and agronomic practices, but also depends on the genetics of the cultivars. Some cultivars have very little incidence of secondary dormancy, while others exhibit levels up to $80 \%$ (Beismann et al., 2003; Gruber et al., 2004; Lutman et al., 2004; Momoh et al., 2002; Pekrun et al., 1997a). If volunteer oilseed rape persistence is to be minimized, plant breeders may be recommended to breed for lower seed dormancy, provided that there is enough genetic variation for dormancy in the gene pool.

The post-harvest period enables an efficient control of emerging weeds by mechanical or chemical means (Tab. 2). HT oilseed rape volunteers and HT wild relatives are equally susceptible to and controlled by conventional herbicides commonly used (Beckie et al., 2001, 2004; Hall et al., 2000, 2003; Salisbury, 2002; Senior and Dale, 2002; Senior et al., 2002). However, the currently used herbicides have a lower efficacy in controlling volunteers compared to glyphosate and glufosinate (Warwick et al., 2004) and may lead to more persistent herbicide residues. Next to the herbicide choice, the timing of application is important. Oilseed rape volunteers, whether non-HT, single HT or multiple HT, are most sensitive to herbicides in the two- to four-leaf stage. In practice, this means that farmers only have a short period of time to treat the oilseed rape volunteers at their most sensitive growth stage since they can emerge early in the growing season and develop quickly (Beckie et al., 2004). Scouting oilseed rape volunteers that remain uncontrolled after weed management allow their control at a later stage thereby preventing seed setting of these plants. The choice of the following crop in a rotation is crucial for an efficient control of oilseed rape volunteers. Control of volunteers in cereals is quite easy and inexpensive offering various herbicide options. In broad-leaved arable and horticultural crops on the other hand, control tends to be much more difficult (Beckie et al., 2004; Gulden, 2003; Lutman et al., 2004; Pekrun et al., 2003; Norris and Sweet, 2002). Increasing the length of the rotation can limit carry-over of HT volunteers into the following oilseed rape crop. The longevity of dormant seeds is thereby crucial, because it will determine the frequency of re-cropping with the same crop but with different GM/non-GM characteristics (Lutman, 2003; Lutman et al., 2004).

\section{CONCLUSIONS}

Given the extent of pollen and seed dispersal in oilseed rape, it is clear that HT feral oilseed rape populations and HT wild relatives will show up as soon as GMHT oilseed rape is grown or imported in Europe. Owing to the low ability of oilseed rape to compete for space with primary colonizers, it is unlikely that HT feral oilseed rape plants will overrun and disrupt natural habitats. In addition, the HT traits in feral oilseed rape plants and wild relatives are not expected to render these plants more invasive or persistent in absence of the relevant herbicide. In field margins and along roadsides and railway lines, however, HT plants will occur, forming transient populations that will flourish. If required, practical measures can be taken to limit the occurrence of HT feral oilseed rape populations and to manage the established populations. The complete prevention of gene flow from transgenic oilseed rape towards sympatric compatible wild relatives such as B. rapa will be impossible.

Due to vertical gene flow, it is also expected that HT weeds will show up in agricultural fields, and that difficulties might be encountered in relation to the adventitious mixing of GM material in non-GM produce. HT weeds will, however, remain susceptible to currently used selective broad-leaf herbicides. Agricultural practices relying on the active ingredients glyphosate or glufosinate may thus require the addition of selective herbicides and/or surfactants in the future. In order to limit the occurrence of HT weeds and to comply with the 
established labelling thresholds, on-farm and off-farm measures will be necessary. Crucial practices may thereby include: (1) restricting seed production of Brassica crops to suitable isolated areas to achieve the established purity standards for certified seed, (2) the use of certified seed to reduce the probability of the adventitious presence of off-types with different HT traits, (3) isolating fields of transgenic HT oilseed rape cultivars to limit out-crossing, (4) harvesting at the correct crop development stage with properly adjusted combine settings to reduce seed losses during harvest, (5) avoiding deep soil inversion for at least 3-4 weeks after harvest and using ploughing as primary tillage before sowing the following crop to ensure maximum germination of shed seeds, (6) using appropriate herbicide treatments and the installation of a competitive crop after oilseed rape to allow efficient weed control in subsequent crops, (7) rotating oilseed rape in a sufficiently long and diverse cropping sequence to deplete volunteers from the seed bank over time, and (8) keeping accurate on-farm records to document the history of a plot.

The widespread implementation of the recommended on-farm and off-farm practices will be crucial. Currently, it remains unclear if some of the proposed measures will be achievable and sufficient to reach the established labelling thresholds. Moreover, should it, for one reason or another, be recommended to "turn the clock back", the task might be hard to accomplish. Even if one stops growing GMHT oilseed rape, the seed bank will continue to produce GM seedlings in a non-GM crop. Without appropriate volunteer management, they may survive and reproduce, and their offspring may refill the seed bank. The only way to get rid of the HT volunteers would be to establish break crops until depletion of the seed bank. And even then a continuous, although small, vertical gene flow would continue between feral oilseed rape populations (in which the transgene(s) might survive) and crops. As quantitative genetics teach us: the introduction of a gene is much easier than the removal of a gene from any population. Therefore, it is important to fully understand the process of vertical gene flow and its environmental and agronomic consequences.

\section{ACKNOWLEDGEMENTS}

We want to thank Allison Snow for her fruitful and constructive comments on the submitted manuscript.

Received February 17, 2004; accepted September 13, 2004.

\section{REFERENCES}

Baker J, Preston C (2003) Predicting the spread of herbicide resistance in Australian canola fields. Transgen. Res. 12: 731-737

Becker H, Karle R, Han S (1992) Environmental variation for outcrossing rates in rapeseed (Brassica napus). Theor. Appl. Genet. 84: 303-306

Beckie H, Hall L, Warwick S (2001) Impact of herbicide resistant crops as weeds in Canada. Proc. Brighton Crop Protect. Conf. - Weeds, pp 135-142

Beckie H, Warwick S, Nair H, Séguin-Swartz G (2003) Gene flow in commercial fields of herbicide-resistant canola (Brassica napus). Ecol. Appl. 13: 1276-1294

Beckie H, Séguin-Swartz G, Nair H, Warwick S, Johnson E (2004) Multiple herbicide-resistant canola (Brassica napus) can be controlled by alternative herbicides. Weed Sci. 52: 152-157

Beismann H, Roller A, Zeitler R (2003) Assessing the number of transgenic oilseed rape seed in the soil seed bank of former release sites. Asp. App. Biol. 69: 209-215

Bilsborrow P, Evans E, Bowman J, Bland B (1998) Contamination of edible double-low oilseed rape crops via pollen transfer from high erucic cultivars. J. Sci. Food Agric. 76: $17-22$

Bing D, Downey R, Rakow G (1995) An evaluation of the potential of intergeneric gene transfer between Brassica napus and Sinapis arvensis. Plant Breed. 114: 481-484

Bing D, Downey R, Rakow G (1996) Hybridisation among Brassica napus, B. rapa and B. juncea and their 2 weedy relatives B. nigra and Sinapis arvensis under open pollination conditions in the field. Plant Breed. 115: 470-473

Blackshaw R, Brandt R, Janzen H, Entz T, Grant C, Derksen D (2003) Differential response of weed species to added nitrogen. Weed Sci. 51: 532-539

Blackshaw R, Brandt R, Janzen H, Entz T (2004) Weed species response to phosphorus fertilization. Weed Sci. 52: 406-412

Chadoeuf R, Darmency H, Maillet J, Renard M (1998) Survival of buried seeds of interspecific hybrids between oilseed rape, hoary mustard and wild radish. Field Crops Res. 58: 197-204

Champolivier J, Gasquez J, Messéan A, Richard-Molard M (1999) Management of transgenic crops within the cropping system. In Lutman P, ed, Gene Flow and Agriculture: Relevance for Transgenic Crops, British Crop Protection Council, pp 233-240

Chèvre AM, Eber F, Baranger A, Kerlan P, Festoc G, Vallee P, Renard M (1996) Interspecific gene flow as a component of risk assessment for transgenic Brassicas. Acta Hortic. 407: 169-179

Chèvre AM, Eber F, Baranger A, Renard M (1997) Gene flow from transgenic crops. Nature 389: 924

Chèvre AM, Eber F, Baranger A, Hureau G, Barret P, Picault H, Renard M (1998) Characterisation of backcross 
Review: Management of herbicide-tolerant oilseed rape in Europe

generations obtained under field conditions from oilseed rape-wild radish $F_{1}$ interspecific hybrids: an assessment of transgene dispersal. Theor. Appl. Genet. 97: 90-98

Chèvre AM, Eber F, Darmency W, Fleury A, Picault I, Letanneur J, Renard M (2000) Assessment of interspecific hybridisation between transgenic oilseed rape and wild radish under normal agronomic conditions. Theor. Appl. Genet. 100: 1233-1239

Chèvre AM, Ammitzbøll H, Breckling B, Dietz-Pfeilstetter A, Eber F, Fargue A, Gomez-Campo C, Jenczewski E, Jørgensen R, Lavigne C, Meier M, den Nijs H, Pascher K, Seguin-Swartz G, Sweet J, Stewart N, Warwick S (2004) A review on interspecific gene flow from oilseed rape to wild relatives. In den Nijs H, Bartsch D, Sweet J, eds, Introgression from Genetically Modified Plants into Wild Relatives, CABI publishing, pp 235-251

Colbach N, Clermont-Dauphin C, Meynard J (2001a) GENESYS: a model of the influence of cropping systems on gene escape from herbicide tolerant rapeseed crops to rape volunteers. I) Temporal evolution of a population of rapeseed volunteers in a field. Agric. Ecosyst. Environ. 83: 235-253

Colbach N, Clermont-Dauphin C, Meynard J (2001b) GENESYS: a model of the influence of cropping systems on gene escape from herbicide tolerant rapeseed crops to rape volunteers. II) Genetic exchanges among volunteer and crop populations in a small region. Agric. Ecosyst. Environ. 83: 255-270

Crawley M, Brown S (1995) Seed limitation and the dynamics of feral oilseed rape on the M25 motorway. Proc. R. Soc. Lond. 259: 49-54

Crawley M, Hails R, Rees M, Kohn D, Buxton J (1993) Ecology of transgenic oilseed rape in natural habitats. Nature 363: 620-623

Crawley M, Brown S, Hails R, Kohn D, Rees M (2001) Transgenic crops in natural habitats. Nature 409: 682-683

Cresswell J, Bassam A, Bell S, Collins S, Kelly T (1995) Predicted pollen dispersal by honey-bees and three species of bumble-bees foraging on oilseed rape - a comparison of three models. Funct. Ecol. 6: 829-841

Cresswell J, Osborne J, Bell S (2002) A model of pollinatormediated gene flow between plant populations with numerical solutions for bumblebees pollinating oilseed rape. Oikos 98: 375-384

Daniell H (2002) Molecular strategies for gene containment in transgenic crops. Nature Biotechnol. 20: 581-586

Darmency H, Fleury A (2000) Mating system in Hirschfeldia incana and hybridisation to oilseed rape. Weed Res. 40: 231238

Dale P (1992) Spread of engineered genes to wild relatives. Plant Physiol. 100: 13-15

Dale P (1994) The impact of hybrids between genetically modified crop plants and their related species: general considerations. Mol. Ecol. 3: 31-36

Deville A, Garnier A, Lecomte J, Adamczyk K, Huet S, Merrien A, Messéan A (2003) Origin and dynamics of feral oilseed rape populations. In Boelt B, ed, 1st European Conference on the Co-existence of Genetically Modified Crops with Conventional and Organic Crops, Research Centre Flakkebjerg, pp 100-101

Dietz-Pfeilstetter A, Zwerger P (2003) Pollen and seed dispersal during the large scale cultivation of transgenic oilseed rape. In Boelt B, ed, 1st European Conference on the Co-existence of Genetically Modified Crops with Conventional and Organic Crops, Research Centre Flakkebjerg, pp 97-99

Downey R (1999) Gene flow and rape - the Canadian experience. In Lutman P, ed, Gene Flow and Agriculture: Relevance for Transgenic Crops, British Crop Protection Council, pp 109-116

Eastham K, Sweet J (2002) Genetically modified organisms (GMOs): the significance of gene flow through pollen transfer. Environmental Issue Report No 28, European Environment Agency

Ellstrand N (1992) Gene flow by pollen: implications for plant conservation genetics. Oikos 63: 77-86

Ellstrand N (2003) Dangerous liaisons? When cultivated plants mate with their wild relatives. In Scheiner S, ed, Synthesis in Ecology and Evolution, the Johns Hopkins University Press

Ellstrand N, Hoffman C (1990) Hybridization as an avenue of escape for engineered genes. BioScience 40: 438-442

Ellstrand N, Prentice H, Hancock J (1999) Gene flow and introgression from domesticated plants into their wild relatives. Annu. Rev. Ecol. Syst. 30: 539-563

Fredshavn J, Poulsen G, Huybrechts I, Rüdelsheim P (1995) Competitiveness of transgenic oilseed rape. Trans. Res. 4: 142-148

Frello S, Hansen K, Jensen J, Jørgensen R (1995) Inheritance of rapeseed (Brassica napus)-specific RAPD markers and a transgene in the cross B. juncea $\times($ B. juncea $\times$ B. napus $)$. Theor. Appl. Genet. 91: 236-241

Friesen L, Nelson A, Van Acker R (2003) Evidence of contamination of pedigreed canola (Brassica napus) seedlots in western Canada with genetically modified herbicide resistance traits. Agron. J. 95: 1342-1347

Gray A, Raybould A (1998) Reducing transgene escape routes. Nature 392: 653-654

Gruber S, Pekrun C, Claupein W (2004) Population dynamics of volunteer oilseed rape (Brassica napus L.) affected by tillage. Eur. J. Agron. 20: 351-361

Guéritaine G, Sester M, Eber F, Chèvre AM, Darmency H (2002) Fitness of backcross six of hybrids between transgenic oilseed rape (Brassica napus) and wild radish (Raphanus raphanistrum). Mol. Ecol. 11: 1419-1426

Gulden R (2003) Secondary seed dormancy and the seed bank ecology of Brassica napus L. in western Canada. Ph.D. thesis, University of Saskatchewan, Saskatoon, Canada

Gulden R, Shirtliffe S, Thomas A (2003a) Harvest losses of canola (Brassica napus) cause large seed bank inputs. Weed Sci. 51: 83-86 
Gulden R, Shirtliffe S, Thomas A (2003b) Secondary seed dormancy prolongs persistence of volunteer canola in western Canada. Weed Sci. 51: 904-913

Hails R, Rees M, Kohn D, Crawley M (1997) Burial and seed survival in Brassica napus subsp. Oleifera and Sinapsis arvensis including a comparison of transgenic and nontransgenic lines of the crop. Proc. R. Soc. Lond. 264: 1-7

Hall L, Topinka K, Huffman J, Davis L, Good A (2000) Pollen flow between herbicide-resistant Brassica napus is the cause of multiple-resistant B. napus volunteers. Weed Sci. 48 : 688-694

Hall L, Good A, Beckie H, Warwick S (2003) Gene flow in herbicide-resistant canola (Brassica napus): the Canadian experience. In Lelley T, Balász E, Tepfer M, eds, Ecological Impact of GMO Dissemination in Agro-Ecosystems, Proceedings of an International OECD Workshop, pp 5766

Hansen L, Siegismund H, Jørgensen R (2001) Introgression between oilseed rape (Brassica napus L.) and its weedy relative B. rapa L. in a natural population. Genet. Resour. Crop Evol. 48: 621-627

Hauser T, Jørgensen R, Østergård H (1998a) Fitness of backcross and $\mathrm{F}_{2}$ hybrids between weedy Brassica rapa and oilseed rape (B. napus). Heredity 81: 436-443

Hauser T, Shaw R, Østergård H (1998b) Fitness of $F_{1}$ hybrids between weedy Brassica rapa and oilseed rape (B. napus). Heredity 81: 429-435

Hauser T, Damgaard C, Jørgensen R (2003) Frequency dependent fitness of hybrids between oilseed rape (Brassica napus) and weedy B. rapa (Brassicaceae). Am. J. Bot. 90: $571-578$

Hobson R, Bruce D (2002) Seed loss when cutting a standing crop of oilseed rape with tow types of combine harvester header. Biosyst. Eng. 81: 281-286

Hoffman C (1990) Ecological risks of genetic engineering of crop plants. BioScience 40: 434-437

Ingram J (2000) Report on the separation distances required to ensure cross-pollination is below specified limits in non-seed crops of sugar beet, maize and oilseed rape. MAFF Project No RG0123

Jenczewski E, Ronfort J, Chèvre AM (2003) Crop-to-wild gene flow, introgression and possible fitness effects of transgenes. Environ. Biosafety Res. 2: 9-24

Jørgensen R, Andersen B, Hauser T, Landbo L, Mikkelsen T, Østergård H (1998) Introgression of crop genes from oilseed rape (Brassica napus) to related wild species - an avenue for the escape of engineered genes. Acta Hortic. 459: 211-217

Jørgensen R, Andersen B, Snow A, Hauser T (1999) Ecological risks of growing genetically modified crops. Plant Biotechnol. 16: 69-71

Jørgensen R, Hauser T, Hansen L, Siegismund H, Andersen B (2003) Gene flow from oilseed rape (Brassica napus) and beet (Beta vulgaris) to wild relatives: effects of herbicide tolerant cultivars. In Lelley T, Balász E, Tepfer M, eds,
Ecological Impact of GMO Dissemination in AgroEcosystems, Proceedings of an International OECD Workshop, pp 67-75

Jørgensen R, Ammitzbøll H, Hansen L, Johannessen M, Andersen B, Hauser T (2004) Gene introgression and consequences in Brassica. In den Nijs H, Bartsch D, Sweet J, eds, Introgression from Genetically Modified Plants into Wild Relatives, CABI publishing, pp 253-277

Kareiva P, Morris W, Jacobi C (1994) Studying and managing the risk of cross-fertilisation between transgenic crops and wild relatives. Mol. Ecol. 3: 15-21

Klinger T, Ellstrand N (1999) Transgene movement via gene flow: recommendations for improved biosafety assessment. In Amman K, Jacot Y, Simonsen V, Kjellsson G, eds, Methods for risk assessment of transgenic plants. III Ecological risks and prospects of transgenic plants, Birkhäuser Verlag Basel, pp 129-140

Lavigne C, Klein E, Vallée P, Pierre J, Godelle B, Renard, M (1998) A pollen-dispersal experiment with transgenic oilseed rape. Estimation of the average pollen dispersal of an individual plant within a field. Theor. Appl. Genet. 96: 886896

Lefol E, Danielou V, Darmency H (1996a) Predicting hybridisation between transgenic oilseed rape and wild mustard. Field Crops Res. 45: 153-161

Lefol E, Fleury A, Darmency H (1996b) Gene dispersal from transgenic crops. II. Hybridisation between oilseed rape and the hoary mustard. Sex. Plant Reprod. 9: 189-196

López-Granados F, Lutman P (1998) Effect of environmental conditions on the dormancy and germination of volunteer oilseed rape seed (Brassica napus). Weed Sci. 46: 419-426

Lutman P (2003) Co-existence of conventional, organic and GM crops - role of temporal and spatial behaviour of seeds. In Boelt B, ed, 1st European Conference on the Co-existence of Genetically Modified Crops with Conventional and Organic Crops, Research Centre Flakkebjerg, pp 33-42

Lutman P, Cussans G, Wright K, Wilson B, Wright G, Lawson H (2002) The persistence of seeds of 16 weed species over six years in two arable fields. Weed Res. 42: 231 241

Lutman P, Freeman S, Pekrun C (2004) The long-term persistence of seeds of oilseed rape (Brassica napus) in arable fields. J. Agricult. Sci. 141: 231-240

Messéan A (1997) Management of herbicide tolerant crops in Europe. Proc. Brighton Crop Protect. Conf. - Weeds, pp 947-954

Mesquida J, Renard M (1982) Study of the pollen dispersal by wind and of the importance of wind pollination in rapeseed (Brassica napus var. oleifera Metzger). Apidologie 4: 353366

Momoh E, Zhou W, Kristiansson B (2002) Variation in the development of secondary dormancy in oilseed rape genotypes under conditions of stress. Weed Res. 42: 446-455

Morgan C, Bruce D, Child R, Ladbrooke Z, Arthur A (1998) Genetic variation for pod shatter resistance among 
Review: Management of herbicide-tolerant oilseed rape in Europe

lines of oilseed rape developed from synthetic B. napus. Field Crops Res. 58: 153-165

Moyes C, Lilley J, Casais C, Cole S, Haeger P, Dale P (2002) Barriers to gene flow from oilseed rape (Brassica napus) into populations of Sinapis arvensis. Mol. Ecol. 11: 103-112

Norris C, Sweet J (2002) Monitoring large scale releases of genetically modified crops (EPG 1/5/84) incorporating report on project EPG 1/5/30: Monitoring releases of genetically modified crop plants

Norris C, Simpson E, Sweet J, Thomas J (1999) Monitoring weediness and persistence of genetically modified oilseed rape (Brassica napus) in the UK. In Lutman P, ed, Gene Flow and Agriculture: Relevance for Transgenic Crops, British Crop Protection Council, pp 255-260

Norris C, Sweet J, Parker J, Law J (2004) Implications for hybridization and introgression between oilseed rape (Brassica napus) and wild turnip (B. rapa) from an agricultural perspective. In den Nijs $\mathrm{H}$, Bartsch D, Sweet J, eds, Introgression from Genetically Modified Plants into Wild Relatives, CABI publishing, pp 107-123

Orson J (2002) Gene stacking in herbicide tolerant oilseed rape: lessons from the North America experience. English Nature Research Reports No 443, English Nature

Orson J, Oldfield J (1999) Gene flow and the practical management of genetically modified crops in the UK. In Lutman P, ed, Gene Flow and Agriculture: Relevance for Transgenic Crops, British Crop Protection Council, pp 247252

Osborne J, Clark S, Morris R, Williams I, Riley J, Smith A, Reynolds D, Edwards A (1999) A landscape-scale study of bumblebee foraging range and constancy, using harmonic radar. J. Appl. Ecol. 36: 519-533

Paul E, Thompson C, Dunwell J (1995) Gene dispersal from genetically modified oilseed rape in the field. Euphytica $\mathbf{8 1}$ : 283-289

Pekrun C, Lutman P (1998) The influence of post-harvest cultivation on the persistence of volunteer oilseed rape. Asp. App. Biol. 51: 113-118

Pekrun C, Lutman P, Baeumer K (1997a) Induction of secondary dormancy in rape seeds (Brassica napus L.) by prolonged inhibition under conditions of water stress or oxygen deficiency in darkness. Eur. J. Agron. 6: 245-255

Pekrun C, Potter T, Lutman P (1997b) Genotypic variation in the development of secondary dormancy in oilseed rape and its impact on the persistence of volunteer rape. Proc. Brighton Crop Protect. Conf. - Weeds, pp 243-247

Pekrun C, Hewitt J, Lutman P (1998) Cultural control of volunteer oilseed rape (Brassica napus). J. Agricult. Sci. 130: 155-163

Pekrun C, Gruber S, Lutman P, Claupein W (2003) The potential impact of volunteer rape as a link between previous and current rape crops - its relevance for managing HT-rape. In Boelt B, ed, 1st European Conference on the Co-existence of Genetically Modified Crops with Conventional and Organic Crops, Research Centre Flakkebjerg, pp 187-189
Pertl M, Hauser T, Damgaard C, Jørgensen R (2002) Male fitness of oilseed rape (Brassica napus), weedy B. rapa and their $\mathrm{F}_{1}$ hybrids when pollinating $B$. rapa seeds. Heredity $\mathbf{8 9}$ : 212-218

Pessel D, Lecomte J, Emeriau V, Krouti M, Messéan A, Gouyon H (2001) Persistance of oilseed rape (Brassica napus L.) outside of cultivated fields. Theor. Appl. Genet. 102: 841846

Price J, Hobson R, Neale M, Bruce D (1996) Seed losses in commercial harvesting of oilseed rape. J. agric. Engng. Res. 65: $183-191$

Rajani S, Sundaresan V (2001) The Arabidopsis myc/bHLH gene Alcatraz enables cell separation in fruit dehiscence. Curr. Biol. 11: 1914-1922

Ramsay G, Thompson C, Neilson S, Mackay G (1999) Honeybees as vectors of GM oilseed rape pollen. In Lutman P, ed, Gene Flow and Agriculture: Relevance for Transgenic Crops, British Crop Protection Council, pp 209-214

Ramsay G, Thompson C, Squire G (2003) Quantifying landscape-scale gene flow in oilseed rape. DEFRA Project RG0216

Raybould A, Gray A (1993) Genetically modified crops and hybridisation with wild relatives: a UK perspective. J. Appl. Ecol. 30: 199-219

Rieger M, Preston C, Powles S (1999) Risks of gene flow from transgenic herbicide-resistant canola (Brassica napus) to weedy relatives in southern Australian cropping systems. Aust. J. Agric. Res. 50: 115-128

Rieger M, Potter T, Preston C, Powles S (2001) Hybridization between Brassica napus L. and Raphanus raphanistrum L. under agronomic field conditions. Theor. Appl. Genet. 103: 555-560

Rieger M, Lamond M, Preston C, Powles S, Roush R (2002) Pollen-mediated movement of herbicide resistance between commercial canola fields. Science 296: 86-88

Roller A, Beismann H, Albrecht H (2003) The influence of soil cultivation on the seed bank of GM-herbicide tolerant and conventional oilseed rape. Asp. App. Biol. 69: 131-135

Salisbury P (2002) Genetically modified canola in Australia: agronomic and environmental considerations. In Downey R, ed, Australian Oilseeds Federation

Scheffler J, Dale P (1994) Opportunities for gene transfer from transgenic oilseed rape (Brassica napus). Trans. Res. 3: 263278

Scheffler J, Parkinson R, Dale P (1993) Frequency and distance of pollen dispersal from transgenic oilseed rape (Brassica napus). Trans. Res. 2: 356-364

Scheffler J, Parkinson R, Dale P (1995) Evaluating the effectiveness of isolation distance for field plots of oilseed rape (Brassica napus) using a herbicide resistance transgene as a selectable marker. Plant Breed. 114: 317-321

Schiemann J (2003) Co-existence of genetically modified crops with conventional and organic farming. Environ. Biosafety Res. 2: 213-217 
Schlink S (1998) 10 years survival of rape seed (Brassica napus L.) in soil. Z. Pflanzenk. Pflanzen. XVI, 169-172

Scott S, Wilkinson M (1998) Transgene risk is low. Nature 393: 320

Scott S, Wilkinson M (1999) Low probability of chloroplast movement from oilseed rape (Brassica napus) into wild Brassica rapa. Nature Biotechnol. 17: 390-392

Senoir I, Dale P (2002) Herbicide-tolerant crops in agriculture: oilseed rape as a case study. Plant Breed. 121: 97-107

Senior I, Moyes C, Dale P (2002) Herbicide sensitivity of transgenic multiple herbicide-tolerant oilseed rape. Pest Manage. Sci. 58: 405-412

Shirtliffe S, Entz M (2004) Chaff collection reduces seed dispersal of wild oat by a combine harvester. Weed Sci. (in press)

Simard M, Légère A, Pageau D, Lajeunnesse J, Warwick $S$ (2002) The frequency and persistence of canola (Brassica napus) volunteers in Québec cropping systems. Weed Technol. 16: 433-439

Simpson E, Sweet J (2001) Consequence analysis of the impact on agriculture and the environment of the release of herbicide tolerant oilseed rape. MAFF report RG0217

Simpson E, Sweet J (2004) Out-crossing between field scale areas of genetically modified herbicide tolerant and other winter oilseed rape cultivars. Pl. Gen. Resources J. (in press)

Simpson E, Norris C, Law J, Thomas J, Sweet J (1999) Gene flow in genetically modified herbicide tolerant oilseed rape (Brassica napus) in the UK. In Lutman P, ed, Gene Flow and Agriculture: Relevance for Transgenic Crops, British Crop Protection Council, pp 75-81

Snow A (2002) Transgenic crops - why gene flow matters? Nature Biotechnol. 20: 542

Snow A, Palma P (1997) Commercialization of transgenic plants. BioScience 47: 86-96

Snow A, Andersen B, Jørgensen R (1999) Costs of transgenic herbicide resistance introgressed from Brassica napus into weedy B. rapa. Mol. Ecol. 8: 605-615

Squire G, Crawford J, Ramsay G, Thompson C, Bown J (1999) Gene flow at landscape level. In Lutman P, ed, Gene Flow and Agriculture: Relevance for Transgenic Crops, British Crop Protection Council, pp 57-64

Squire G, Begg G, Askew M (2003) The potential for oilseed rape feral (volunteer) weeds to cause impurities in later oilseed rape crops. DEFRA project RG0114

Sweet J (2003) Pollen dispersal and cross-pollination. In Boelt B, ed, 1st European Conference on the Co-existence of Genetically Modified Crops with Conventional and Organic Crops, Research Centre Flakkebjerg, pp 21-32

Sweet J, Shepperson R, Thomas J, Simpson E (1997) The impact of releases of genetically modified herbicide tolerant oilseed rape in the UK. Proc. Brighton Crop Protect. Conf. Weeds, pp 1291-1302
Thomas D, Breve M, Raymer P (1991) Influence of timing and method of harvest on rapeseed yield. J. Prod. Agric. 4: 266-272

Thompson C, Squire G, Mackay G, Bradshaw J, Crawford J, Ramsay G (1999) Regional patterns of gene flow and its consequences for GM oilseed rape. In Lutman P, ed, Gene Flow and Agriculture: Relevance for Transgenic Crops, British Crop Protection Council, pp 95-100

Tiedje J, Colwell R, Grossman Y, Hodson R, Lenski R, Mack R, Regal P (1989) The planned introduction of genetically modified organisms: ecological considerations and recommendations. Ecology 70: 298-315

Timmons A, O'Brien E, Charters Y, Dubbels S, Wilkinson M (1995) Assessing the risks of wind pollination from fields of genetically modified Brassica napus ssp. oleifera. Euphytica 85: 417-423

Timmons A, Charters Y, Crawford J, Burn D, Scott S, Dubbels S, Wilson N, Robertson A, O'Brian E, Squire G, Wilkinson M (1996) Risks from transgenic crops. Nature 380: 487

van Tienderen P (2004) Hybridization in nature: lessons for the introgression of transgene into wild relatives. In: den Nijs H, Bartsch D, Sweet J, eds, Introgression from Genetically Modified Plants into Wild Relatives, CABI publishing, pp 7-25

Walklate P, Hunt J, Higson H, Sweet J (2004) A model of pollen-mediated gene flow for oilseed rape. Proc. R. Soc. Lond. 271: 441-449

Warwick S, Beckie H, Small E (1999) Transgenic crops: new weed problems for Canada? Phytoprotection 80: 71-84

Warwick S, Simard M-J, Légère A, Beckie H, Braun L, Zhu B, Mason P, Séguin-Swartz G, Stewart N (2003) Hybridization between transgenic Brassica napus L. and its wild relatives: B. rapa L., Raphanus raphanistrum L., Sinapis arvensis L., and Erucastrum gallicum (Willd.) O.E. Schulz. Theor. Appl. Genet. 107: 528-539

Warwick S, Beckie H, Simard M-J, Légère A, Nair H, Séguin-Swartz G (2004) Environmental and agronomic consequences of herbicide-resistant (HR) canola in Canada. In den Nijs H, Bartsch D, Sweet J, eds, Introgression from Genetically Modified Plants into Wild Relatives, CABI publishing, pp 323-337

Wilkinson M, Charters Y, Timmons A, Dubbels S, Robertson A, Wilson N, Scott S, O'Brian E, Lawson H (1995) Problems of risk assessment with genetically modified oilseed rape. Proc. Brighton Crop Protect. Conf. - Weeds, pp 1035-1044

Wilkinson M, Davenport I, Charters Y, Jones A, Allainguillaume J, Butler H, Mason D, Raybould A (2000) A direct regional scale estimate of transgene movement from genetically modified oilseed rape to its wild progenitors. Mol. Ecol. 9: 983-991 